\title{
HISTORY
}

\section{A COMPARATIVE STUDY OF POLITICAL AND MILITARY SPACE BETWEEN LUOYANG CITY IN HAN AND WEI DYNASTIES AND ROME IN IMPERIAL PERIOD}

\author{
Jin Lipeng, \\ PhD of department history of the Belarusian State University, Minsk, Belarus
}

DOI: https://doi.org/10.31435/rsglobal_ws/30062020/7124

\section{ARTICLE INFO}

Received: 10 April 2020

Accepted: 16 June 2020

Published: 30 June 2020

\section{KEYWORDS}

Ancient Luoyang City Ancient Roman City Political and Military Space \begin{abstract}
To study the political and military functions of ancient eastern and western city-states, the masterpieces should be ancient Luoyang city and ancient Roman city. This article takes Hanwei ancient city and ancient Roman city as examples, reviews the history, and briefly analyzes its political and military functions in ancient times. The Eastern and Western civilizations provide some suggestions for follow-up researchers.
\end{abstract}

Citation: Jin Lipeng. (2020) A Comparative Study of Political and Military Space Between Luoyang City in Han and Wei Dynasties and Rome in Imperial Period. World Science. 6(58), Vol.3. doi: 10.31435/rsglobal_ws/30062020/7124

Copyright: (C) 2020 Jin Lipeng. This is an open-access article distributed under the terms of the Creative Commons Attribution License (CC BY). The use, distribution or reproduction in other forums is permitted, provided the original author(s) or licensor are credited and that the original publication in this journal is cited, in accordance with accepted academic practice. No use, distribution or reproduction is permitted which does not comply with these terms.

Political and military space is the most important building facilities for a capital city to govern the country and defend against foreign invasion, mainly including palace buildings, squares, city walls, gates, arsenals, central government buildings, etc.

Political and Military Space of Luoyang City in Han and Wei Dynasties.

According to archaeological investigation, the capital of Luoyang in the Eastern Han Dynasty is a vertical rectangle in the north and south. According to actual measurement, the residual length of the eastern wall is 3,895 meters and the width is 14 meters. The western wall has a residual length of 3510 and a width of about 20 meters. The residual length of the northern wall is 2820 meters and the width is about $25 \sim 30$ meters. The distance between the east and west walls of the south wall is calculated to be 2460 meters. With the walls washed away by Luo River in the southern section of the east and west walls, the length of the whole city circle is close to 14 kilometers. Cao Wei and the Western Jin Dynasty continued to use the cities of the Eastern Han Dynasty. The location and number of gates did not change, but their names changed a lot. Luoyang City in the Northern Wei Dynasty was restored and expanded according to Luoyang City in the Wei and Jin Dynasties. The Yong Gate on the West City Wall moved about 500 meters to the north and was renamed western Gate. A new Chengming Gate was built near Jin Yong City in the northern section of the West City Wall, with 13 gates. In the second year of Emperor Xuanwu's reign (501), he added foreign Guo Cheng. The triple city circle of palace, Inner City and Outer Guo Cheng formed in the Northern Wei Dynasty was the first capital city in ancient China.

Horse noodles were one of the main defense facilities in ancient Chinese cities. According to archaeological exploration, a total of 7 horse-faced sites have been found in the eastern section of the northern wall of the inner city and the northern section of the western wall, including 4 in the northern section of the western wall and 3 in the eastern section of the northern wall, with the horse-faced sites 
separated by $110 \sim 120$ meters. The time when Luoyang Han and Wei ancient cities built horse noodles was not only the earliest in the mainland cities of past dynasties, but also an earlier example in the known ancient city sites in the mainland of China.

The imperial city of Luoyang in the Han and Wei Dynasties experienced continuous expansion from the Western Zhou Dynasty. In the Qin Dynasty and the Western Han Dynasty, the system of the two palaces in the north and south was the prominent feature of the palace layout in the city site. Liu Xiu, Emperor Guangwu of the Eastern Han Dynasty, inherited the layout of the two palaces in the north and south. In the Cao Wei Dynasty, the southern palace was abandoned, the North Palace was renovated and expanded, and a single palace system centered on the North Palace was formed, which is of great significance in the history of capital development.

The main entrance to the south of palace in the Northern Wei Dynasty is the site of the first palace gate. The main entrance of Luoyang Palace City is called Chang He Gate (as shown in Figure 1). It began when Emperor Ming of Luoyang Palace was newly built in the early Cao Wei Dynasty and changed the pheasant gate to Chang He Gate. This gate continued to be used from the Western Jin Dynasty to the Northern Wei Dynasty. Changhe Gate is located in the west section of palace's south wall. In the north, Palace Gate 2 and Gate 3 are facing the Taiji Hall of the main hall, while in the south, it is directly facing Tongtuo Street and Xuanyang Gate, the main entrance of the inner city. The foundation of the palace-style gate building is located in the north of the gap in the palace wall. The huge rammed earth towers on both sides of the gate are located at both ends of the gap in the palace wall, with unique shape. In front of the door, the left and right towers are symmetrically distributed, with an interval of 41.5 meters, forming a square between towers. The plane of the towers is a curved ruler-shaped sub-towers with one mother towers and two sub-towers. The palace gate gate is the most important ceremonial building in the capital city due to its important location and unique shape. It has important academic value for the study of the unique capital gate gate system in ancient China.

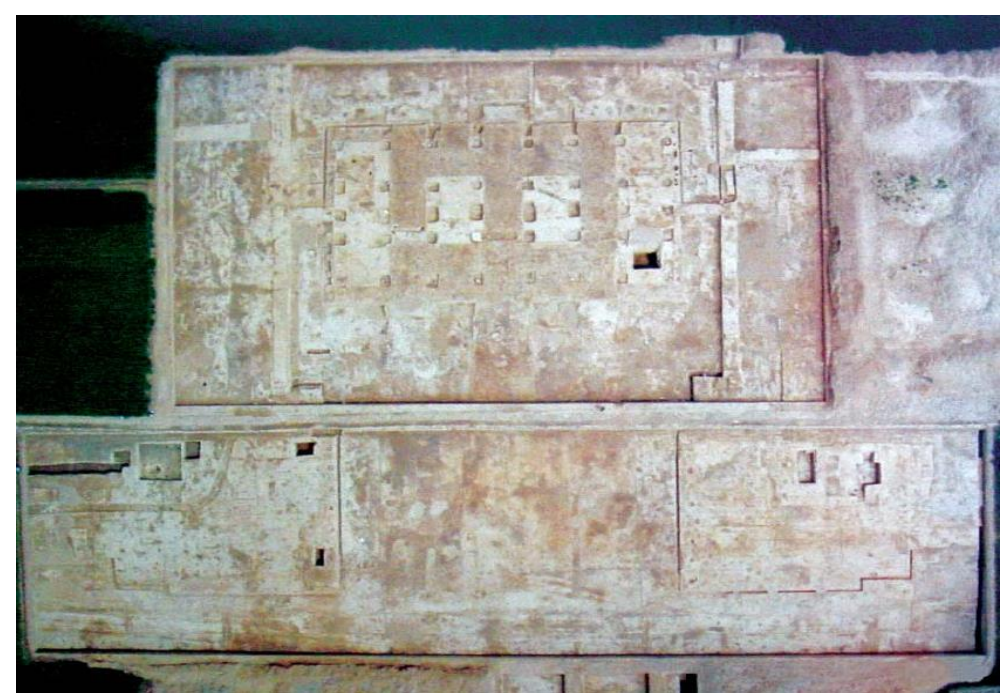

Fig. 1 A plan view of Chang He Gate

The second gate on the front of the imperial city of the Northern Wei Dynasty is the site of the second gate. Located 95 meters to the north of the Changhe Gate in palace, there is an east-west cross street in front of the gate. It is presumed that it may be the site of Zhiden recorded in the literature. According to the investigation, the gate site is basically the same in scale, shape and structure as Changhe Gate, except that there are no double gates. It is also a three-way palace gate building. The third gate on the front of the imperial city of the Northern Wei Dynasty is the site of the 3rd gate. Located 80 meters north of the No.2 Palace Gate and 300 meters south of the Tai Ji Hall, it is the last barrier building directly in front of the Tai Ji Hall. According to investigation, only the southern half of the gate site in the Northern Wei Dynasty was left, and the northern half was destroyed by the unfinished large rammed earth foundation site in the late Northern Dynasty. The most important main hall in the center of palace in the Northern Wei Dynasty is the ruins of Tai Ji Hall. Located in the middle of the northern end of the southern district of the West Road axis, it is commonly known as "Golden Palace" and "Chaowang Palace". The three main gates directly facing palace in the south-the 
No.3 Palace Gate, the No.2 Palace Gate and the Chang He Gate-are the places where emperors hold large-scale court meetings and deal with major events. According to investigation, the palace courtyard where the Tai Ji Hall is located is large in scale. The foundation of the central temple is located in the middle of the northern part of the palace courtyard. The rammed earth foundation on the ground is about 100 in length from east to west, 60 in width from north to south, 2 meters in residual height and 6 meters in thickness. According to the remaining relics, there are slow traces and tread traces found in front of and behind the platform foundation of the Tai Ji Hall. In the middle of the west wall of Palace, there was found the West Gate of the palace, the Shenhu Gate, which was equipped with double gates. The Shenhu Gate was an important passage for officials to go to court and was the only gate that could directly reach the TaiJi Hall, the main hall of Miyagi in the Northern Wei Dynasty.

In the southeast and south of the palace, there are official building sites such as Marshal House, Sikong House and Situ House. The northern part of palace is the arsenal, which has found a large number of weapons remains.

\section{Political and military space in Rome.}

Seville City Wall was built in the 6th century BC in the early imperial period. With the expansion of the city, it lost its defensive function and a new city wall was built in the 3rd century during the reign of Aurelian. There are a total of 16 gates, the earliest of which was the Capena Gate, followed by the construction of the Corina Gate, the Verminale Gate and the Caeri Montana Gate. The Augustus period rebuilt the Osquilino Gate, the Caeri Montana Gate, the Three Gates and the River Gate.

The city wall of Olelian was built in 271 and was largely completed by the time of Olelian and finally completed by the time of Plobe. Its direction not only considered topographic, strategic and economic factors, but also incorporated some previous buildings due to time constraints. The gate is divided into double arch type, single arch with tower type and single arch without tower type.

As the most important public space in ancient Rome, the square has become a symbol of personal and royal authority after the emperor's transformation. The new imperial square has become a symbol of the imperial dynasty and a means of political propaganda, showing the authority of the rulers, which has changed greatly due to the emperor's preferences.

The Roman Square, also known as the Grand Square, is the most central and longest-lasting area in Rome. Located in the valleys of the Palatino and Campido Mountains. The construction activities of the square can be divided into four phases, lasting for a long time. In the early days of the Empire, the square layout plane was trapezoidal and consisted of three floors of buildings inside and outside. There are mainly Amelia Hall, Sewer Goddess Small Sanctuary, Double-Sided Temple, Parliament, Blackstone, Giulio Senate such as, Seville Arc de Triomphe, Golden Milestone and Rome Center, National Prison, Central District, Giulio Hall, Augustus Arc de Triomphe, Vesta Atrium, Venus and Rome Temple, Tiberius Arch, etc.

Imperial Square includes Caesar Square, Augustus Square, Nerva Square, Trajan Square and Peace Square. Caesar Square is also called Julio Square. The square is rectangular, with Caesar's horse riding sculpture in the center and the central axis running from northwest to southeast. The central axis of Augustus Square runs from northeast to southwest. In the middle of the north side of the Square is the Temple of Avengers and Ares, and colonnades are on the east and west sides. The Peace Square was originally called the Temple of Peace. The square was originally located in the market. In the southeast is Constantine Hall, which is rectangular. Nerva Square is also called Transition Square. Its plane is narrow and long. The northern end is Minerva Temple and the southern end is slightly curved. Trajan Square was originally a complex of buildings including the consul's office, archives and library. Later, the buildings were demolished and the square was set up. It consists of an open-air area, Upiya Hall, Trajan Merit Pillar and Library.

Augustus merged a large number of houses in Mount Palatino and Nero built the Golden House, expanding the palace to Opio Peak. Julio Claudio and Flavi dynasties were in the "pre-palace era". Although the emperors lived in the same area, they all had their own mansions. The Augustana Palace was built at the end of Tumishan of the Flavi Dynasty, officially opening the "Palace Age". The main palaces include Augustus, Livia, Tiberius, Transition, Gold House, Ostana Palace, etc.

The permanent residence of the Senate is in the Giulio Senate in Rome Square, with archives and the Senate Trial Court. In addition, there is the Octavian Senate, which is held in the Julio Election Gallery and is located near the present Venice Palace, St. Mark's Church and other places. 
The court of consuls was built in the parliament in the middle of the 2nd century BC and later demolished. Post-reconstruction with Rome Square. The remains of the city consul's office can no longer be found, but the inscription is recorded on the west side of Trajan Bathing Beach in Mount Osquillino and mainly consists of a secretariat, a confidential office and a court.

\section{Comparative Study.}

The Han Dynasty of China inherited the centralized system of the Qin Dynasty of China. The local power was vested in the central government, the central power was vested in the emperor, and the officials were headed by the prime minister. During the period of Emperor Wu of the Han Dynasty, unification was gradually completed and imperial power was strengthened. Emperor Cheng of the Han Dynasty transferred the real power of officials to ministers. During the Cao Wei and Western Jin Dynasties, Shangshu Province was not a similar official to the prime minister, but became an independent government organ. The Northern Wei Dynasty was a transitional period to the system of three provinces and six departments. Although most of the time it was in a state of split war, the management system of this period still came down in one continuous line with the Qin and Han Dynasties. The administrative system of the Roman Empire presents the characteristics of "dual politics", that is, the coexistence of constitutional monarchy and formal republic. With the development of history, the characteristics of constitutional monarchy become more and more obvious. The power of the imperial consul was actually suspended and allowed to be shortened. Magistrates still retain their basic functions in civil justice and criminal justice, but their rights in criminal justice gradually decline. Some of the prosecutor's rights are owned by the emperor. The People's Assembly, the Senate and all levels of officials were restricted by the emperor's rights to varying degrees.

The city wall represents a kind of boundary, a double division in urban space and management system. The city walls of Luoyang City in Han and Wei Dynasties and Rome City in the imperial period are the basis for the division of important urban facilities, but there are differences in the specific functions and division degree of urban space. The city wall of Luoyang City in Han and Wei Dynasties basically synchronized with the change of dynasties in the Eastern Han Dynasty, Cao Wei, Western Jin Dynasty and Northern Wei Dynasty. Apart from the consideration of military defense, geographical characteristics and architectural layout, it basically followed the unified architectural concept of urban planning. The city wall was generally rectangular in the north and south direction, with the system of city gates and the setting of defense facilities. The space inside and outside the city wall has a fundamental legal difference, thus the people inside and outside the city also have different identity differences. Internally, there are palace walls, Li Fang walls and market walls, which have strong characteristics of feudal military management.

Rome's Seville City Wall has maintained its original direction and appearance in several centuries, although it has been repaired and rebuilt. Roman city is different from Luoyang city in Han and Wei Dynasties in the meaning of serving as a boundary, and the meaning of city wall is not as good as "sacred boundary". The space within the sacred boundary is purified and has multiple meanings such as law, concept and religion. The original construction of the city wall was based on the need for defense. The setting of the gates was mainly based on convenient transportation. Later, some gates were given commemorative significance, which was completely different from the setting of the gate specifications of Luoyang City in Han and Wei Dynasties. For example, the doorway in the middle of Luoyang City with three doorways can only be used by emperors, while civilians can only use the small doorways on both sides.

In terms of the political center of the capital city, the political center of Luoyang City in Han and Wei Dynasties was the Imperial Palace, where the royal family's government affairs and residence were located. The palace system of Luoyang City in Han and Wei Dynasties, which inherited the remnants of Qin and Han Dynasties and started the prosperous times of Sui and Tang Dynasties, played an important role in the history of ancient Chinese capital system. The centered on Tai Ji Hall, is one of the largest buildings in Luoyang City of Han and Wei Dynasties and even in ancient China. This group of palace buildings, which have been strictly designed and planned in a unified way, is also a brand-new palace building pattern in ancient Chinese capitals. The layout of the capital city's single building axis marked by the establishment of the Tai Chi Hall, the single palace city in the north and the middle, and the central main hall in the Tai Ji Hall; The Tai Ji Hall is a great dynasty, and the East and West halls juxtaposed on the east and west sides are the East and West Hall system of the common dynasty. In front of the main hall of the center, there are three palace gates, and the "five gates and 
three dynasties" system, which is arranged in the north and south of the three main halls of the palace city, ushered in a new era of the ancient Chinese capital system and the layout of the palace city, and had a profound impact on the development of the capital system of future generations. Palace is regarded as a forbidden area and ordinary people cannot enter it.

The political centers recognized by the people of the Roman Empire are more inclined to squares. With the demise of the Republic, the center shifted from Rome Square to Empire Square, which was transformed into a political propaganda center. The buildings inside Imperial Square all embody the political symbols of Imperial rule. Imperial Square is square, surrounded by walls and colonnades, with symmetrical layout and prominent center. The focus of the building is the temple, where the head of state holds public activities. The square is an open and public space that anyone can enter and carry out political propaganda to those who enter the square. Temples, sculptures and memorial buildings are important elements of the square. The administrative functions are mainly shared by the emperor's residence in Mount Palatino and the Senate in the square. The emperors in the early days of the empire did not have fixed palaces, which were not established until the period of Tumi Shan. Different from Luoyang City in Han and Wei Dynasties, the emperor's residential area has only a single wall outside the palace, and there is no defense around the palace.

In terms of military affairs, Luoyang City has a large number of troops, including court troops and capital guard troops. The military strength of Rome City is also in the hands of the emperor. However, the military strength is mainly stationed outside the sacred border. The lack of effective containment among various troops is easy to cause unstable factors. The administrative agencies of Luoyang City in Han and Wei Dynasties and Rome City in the Empire both have the same characteristic: the government and temple are mixed, and some government offices are set up in ancestral temples and temples.

Conclusions. Through historical review and analysis, I believe that the ancient Luoyang City was the capital of the Han and Wei Dynasties and the center of Eastern politics and military affairs. Its construction and design were mainly characterized by imperial power and military defense. The ancient Roman city was a masterpiece of ancient Western civilization. Combining business and military defense as one, the two ancient Chinese and Western cultural centers have the same function and function, each with its own characteristics, reflecting the wisdom of the ancients.

\section{REFERENCES}

1. Han Wei Luoyang City discovered the East Han coal burning kiln site, Archaeology 19972

2. Duan Pengqi: "Discussion on the Form of the Ancient City of Luoyang in the Han and Wei Dynasties", Luoyang Cultural Relics and Archeology Series, Science Press, 1999.

3. Luoyang Task Force, Institute of Archaeology, Chinese Academy of Social Sciences: "Excavation of Horse Noodles at the North Wall of Luoyang, the Old City of Han and Wei Dynasties", Archaeology, No.8, 1986.

4. Luoyang Task Force, Institute of Archaeology, Chinese Academy of Social Sciences: "Excavation of the Chunmen Site in the Northern Wei Dynasty in Luoyang City, Han and Wei Dynasties", Journal of Archaeology, 1988 (9).

5. Meng Fanren: "A Preliminary Study of the Guocheng Formation Outside the Luoyang City of the Northern Wei Dynasty", Journal of the Chinese History Museum, 1982, 4.

6. Luoyang Task Force of the Institute of Archaeology, Chinese Academy of Sciences: "The Han Dynasty and the Luoyang City Site and the Unearthed Wavin”, “Archaeology”, Issue 4, 1973

7. William Sewell, Marc Bloch and the Logic ofComparative History, History and Theory, 1976 (6).

8. R. Palmer, The Age of Democratic Revolution, Princeton: Princeton University Press, 1959.

9. C. Black, The Dynamics of Modernization: A Studyin Comparative History, New York: Harper\&Row, 1966. 